\title{
Continuity and Change in Two Bulgarian Communities: A Sociological Profile
}

The ways in which members of a community think, act, or believe are always changing. Sometimes the pace of change is imperceptibly slow; at other times it is so rapid that it can distinguish an era from its recent past. The rural communities of Bulgaria have experienced rapid change over the last three decades. It began on September 9, 1944, when the Bulgarian monarchy was overthrown and the Bulgarian Communist Party emerged to lead Bulgaria on a path of socialist development. The seizure of power was a revolutionary act but, more important, from a sociological point of view, it was an act that made revolutionary change possible. My purpose is to illustrate several ways in which Bulgarian rural communities have participated in the revolutionary transformation of community and family life in the 1970s.

This study is based on research conducted in 1975-76 in two Bulgarian communities-Dragalevtsy and Obnova. ${ }^{1}$ Dragalevtsy was the subject of Professor Irwin T. Sanders's pioneering 1934 study that was reported in Balkan Village. ${ }^{2}$ With his encouragement and his original data, I returned to examine how community and family life had changed in Dragalevtsy over the last forty years. Part of my research involved interviewing members of sixty households, half of whom are descendants of the thirty persons Professor Sanders interviewed at that time. ${ }^{3}$ Comparative data for these two periods-one presocialist and the other socialist-provide a unique opportunity to consider four decades of change in certain prewar attributes of the Dragalevtsy villagers.

Dragalevtsy was a Balkan village in 1934; today it is, in many ways, a Balkan suburb. ${ }^{4}$ Most of the community's growing population now take the twenty-minute bus ride to work in the capital city of Sofia. In order to expose the changes in Dragalevtsy that may be attributable to its proximity to Sofia, I used the same research design in the village of Obnova, a more remote Bulgarian community, located thirty-one kilometers east of the city of Pleven in northern Bulgaria..$^{5}$ Obnova is a progressive agricultural community with a distinguished history of participation in the revolutionary events of the early 1940s. Unlike Dragalevtsy, Obnova has experienced a decline in population because of the out-migration of many village youths pursuing higher education

1. The research was made possible by the International Research and Exchanges Board, New York, and in cooperation with the Institute of Sociology of the Bulgarian Academy of Sciences.

2. Irwin T. Sanders, Balkan Village (Lexington: University of Kentucky Press, 1948).

3. The remaining thirty respondents were selected by a random sample drawn from the local council's registry of residents. The sample was stratified by age.

4. Dragalevtsy is now a part of the seventh district of Sofia which includes thirteen outlying communities that surround the capital city. The district has 120,000 residents.

5. Forty-seven Obnova residents were interviewed. They were selected by a random sample drawn from the village's registry of residents. The sample was stratified by age. 
or nonagricultural, urban employment. ${ }^{6}$ Also, in contrast to Dragalevtsy, all but 100 of Obnova's 1,656 employed residents work in the local community, half of them on a cooperative farm. The contrast between these two communities -one a commuter suburb, the other an agricultural village-raises some important questions about the different ways in which Bulgarian communities are participating in the socialist reconstruction of the Bulgarian countryside. For the purpose of this paper, however, I will emphasize some of the ways in which both Dragalevtsy and Obnova reveal the same general processes of socialist development.

In 1944, Dragalevtsy and Obnova shared one outstanding characteristic - they were both peasant communities. They were not unique in this respect, because, before World War II, Bulgaria was often called part of the "peasant belt of Europe," stretching from the Baltic Sea to the Aegean. Although there are many definitions of the peasantry, three of the most consistently cited social characteristics are: (1) a strong attachment to private land, (2) a narrow; village social orientation, (3) a strong sense of traditional patriarchal familism. Each of these attributes described the villagers of Dragalevtsy and Obnova prior to World War II. Professor Sanders documented these features in Dragalevtsy in the 1930s, and my discussions with elders and officials in Obnova indicate that Obnova villagers were not unlike those in Dragalevtsy, at least in these three respects.

Many of the characteristics of presocialist peasant life in Bulgaria were not necessarily obstacles to socialist development after the revolution in 1944. Some traditional aspects of presocialist life have been conducive to socialist development, others have been tolerated or adapted by socialist policymakers. ${ }^{7}$ The three characteristics mentioned above, however, are clearly inimical to the goals of socialist rural development as articulated by the Bulgarian Communist Party since 1944. Strong attachment to private land is incompatible with socializing the means of agricultural production. A narrow, village social orientation is contrary to the party's goal of eliminating distinctions between village and town. Finally, strong patriarchal familism of Bulgaria's prewar peasants obstructs the socialist goal of emancipating individuals, especially women, from presocialist family forms. Therefore, in 1944, the Bulgarian Communist Party faced the choice of introducing radical reforms in the countryside or enduring certain ideological anomalies, and it chose radical change. By contrasting the contemporary situation in Dragalevtsy and Obnova with the three presocialist, peasant attributes listed above, I hope to illustrate aspects of both the continuity and the change in Bulgarian community and family life in the 1970s.

Before World War II, Bulgaria was part of the "agricultural half of Europe," supplying foodstuffs and raw material to the industrial half of Europe, especially

6. In 1946 , the population of Obnova was 5,600 ; in $1956,5,400$; in $1965,4,254$; in 1975 , 3,511. In 1934, the population of Dragalevtsy was 2,204 ; in $1946,3,296$; in $1956,3,111$; in $1975,3,986$.

7. The various responses of Bulgaria's socialist leaders to selected presocialist traditions are discussed in Roger Whitaker, "Experiencing Revolutionary Change: The Role of Tradition," paper presented to the Second International Conference on Bulgarian Studies, in Varna, Bulgaria, June 1978. 
Germany. Like Bulgaria as a whole, about 80 percent of the people in Dragalevtsy and Obnova were engaged in agriculture in 1934. The agrarian structure of the prewar Balkan village was characterized by fragmented landholdings, primitive farming methods, and serious problems of unemployment and underemployment. ${ }^{8}$ The organization of household roles and relations was closely tied to the agrarian structure. Labor for the family farm was usually provided by family members themselves. Household division of labor centered around the requirements of the farm operation, and the male head of the household held authority over his subordinate wife and over his children who stood to inherit the land. In addition, the community's social structure was closely linked to the agrarian system, and ownership of land was one of the major determinants of social status in the village. Aside from a small intelligentsia in Dragalevtsy and Obnova (consisting of teachers, a doctor, a priest, and a mayor), the distribution of community power and prestige was basically determined by the size of a family's landholding. In short, farming privately owned land was the primary economic activity of most villagers and the anticipated future of the growing generations within the village. ${ }^{9}$ The situation in the 1970 s is remarkably different.

Using Lenin's “cooperative plan" and the kolkhoz experience of the Soviet Union, Bulgaria initiated radical reforms in its agrarian structure soon after 1944. ${ }^{10}$ Progressive consolidation of fragmented landholdings-initially through voluntary contributions of land to cooperatives and later by means of intense pressure-and increased capital investments, made possible mostly by grants or long-term loans from the Soviet Union, have allowed Bulgarian agriculture to become rapidly mechanized and specialized in the 1970s. Scientific and technical improvements have greatly reduced labor requirements of Bulgarian agriculture. By 1970, the percentage of the labor force employed in agriculture had been reduced from the prewar level of 80 percent to less than 37 percent. ${ }^{11}$ The reduction in the number of people engaged in agriculture (both in absolute numbers and as a proportion of the work force) has been even more dramatic in Dragalevtsy because of its proximity to Sofia and the resulting opportunity to commute to the many jobs in the capital. Dragalevtsy today has only two hundred full-time and one hundred fifty seasonal workers employed in agriculture. By contrast, approximately eight hundred residents of Obnova, which has a population roughly equivalent to Dragalevtsy, are employed in agriculture.

8. Between 1934 and 1944 , the number of homesteads increased by 22.6 percent, and the total number of fields reached twelve million (see Mincho Kyurkchiev, Bulgarian Agriculturc Today and Life in the Villages [Sofia, 1974], p. 9). Estimates of the surplus agricultural population before World War II suggest that as much as one-third of the agricultural population was redundant (see, for example, Paul Rosenstein-Rodan's estimates referred to in Robert Wolff, The Balkans in Our Times [Cambridge, Mass.: Harvard University Press, 1974], pp. 50-51; Pawel Egoroff's estimates cited in Alexander Gerschenkron, Economic Backwardness in Historical Perspective [Cambridge, Mass.: Harvard University Press, 1966], pp. 224-25; or Kyurkchiev, Bulgarian Agriculture Today and Life in the Villages, p. 10).

9. Ninety-one percent of the farmers in Dragalevtsy in 1934 were working land that they had inherited from their fathers.

10. For a brief description of the phases of agricultural reorganization, see Vassil Baev, A Glance at Bulgaria (Sofia, 1975).

11. Roy E. H. Mellor, Eastern Europe: A Geography of the Comecon Countries (New York: Columbia University Press, 1975), p. 309. 
The standard of living of the farmers in Dragalevtsy and Obnova has risen considerably in recent years. Generally speaking, industrial work provides wages that are 10 to 15 percent higher than those for farm work, but the agricultural worker is often said to have a better standard of living than the industrial worker. The cooperative farmer has the use of an auxiliary plot (ranging up to one-half hectare in size ${ }^{12}$ ) made available by the farm, and he may raise animals privately. The produce from both activities may be used to meet the family's food needs or sold in local markets or to the state for the same price that the cooperative farm receives for its products. ${ }^{13}$ The cooperative farmer is able to acquire enough land from the farm to build a house. He is guaranteed at least fourteen days of vacation per year and a pension (at the age of fifty-five for women, sixty for men) that is equivalent to that of an industrial worker. ${ }^{14}$ Despite the improved financial situation of the cooperative farmer in Dragalevtsy and Obnova today, the policies of the Bulgarian government designed to socialize the means of agricultural production have served to obviate the "attachment to private land" that was so apparent in the prewar village, especially among today's youth. This becomes clear when we consider the age structure of the cooperative farm members, the occupational aspirations of village youth, or the household division of labor on the auxiliary plot of land.

The average age of the workers on the Vitosha cooperative farm, of which Dragalevtsy is a member, is between fifty-five and fifty-eight. ${ }^{15}$ Unskilled laborers are slightly older, whereas skilled technicians and agricultural specialists are considerably younger. None of the young technicians or specialists on the Vitosha cooperative, however, is from Dragalevtsy. The two hundred Dragalevtsy residents who work on the farm are mostly older workers, a substantial proportion of whom is above the retirement age. By contrast, in Obnova a significant number of young people work on the farm, although one-fourth of the eight hundred cooperative farm workers are pensioners. The majority of young workers are women engaged in unskilled field work; many of the skilled technicians and specialists are also from Obnova. The higher proportion of village youth working in agriculture in Obnova, as compared with Dragalevtsy, is explained by the fact that Obnova residents who seek nonagricultural employment must usually move outside the local community. Those who remain in the village have few alternative employment opportunities.

Change in the traditional "attachment to private land" becomes more obvious when the occupational aspirations of today's young people in Dragalevtsy and Obnova are considered. For this study, I asked the sixty-six students in the eighth-grade classes in Dragalevtsy and Obnova to write a short essay on their

12. A hectare is equal to two and a half acres.

13. State authorities forecast that personal plots will not be necessary or desirable once cooperative farms are able to satisfy all of the needs of their members. For the foreseeable future, however, the personal plots are recognized as a valuable supplement to Bulgaria's agricultural production.

14. Pension benefits and regulations are detailed in Legal Status of Women in Bulgaria (Sofia, 1976), p. 40.

15. Dragalevtsy is one of six villages which make up the Vitosha cooperative farm, formed in 1957 by merging the various village cooperatives. In 1974, the Vitosha cooperative farm merged with twelve other cooperatives to form what is called the Sredets "agroindustrial complex." 
Table 1. Occupational Aspirations of Eighth-Grade Students, 1975-76

\begin{tabular}{lcc}
\hline Occupation & $\begin{array}{c}\text { Number in } \\
\text { Dragalevtsy }\end{array}$ & $\begin{array}{c}\text { Number in } \\
\text { Obnova }\end{array}$ \\
\hline Actress & 0 & 1 \\
Athlete & 2 & 1 \\
Car Mechanic & 1 & 0 \\
Carpenter & 0 & 1 \\
Chauffeur & 0 & 0 \\
Chemist & 1 & 1 \\
Criminologist & 0 & 0 \\
Doctor & 1 & 1 \\
Druggist & 0 & 3 \\
Engineer & 2 & 1 \\
Food Service Worker & 0 & 1 \\
Hairdresser & 0 & 1 \\
Lathe Operator & 0 & 0 \\
Lawyer & 1 & 0 \\
Military Officer & 2 & 0 \\
Musician & 1 & 2 \\
Nurse & 0 & 1 \\
Pilot & 4 & 7 \\
Radio/Television Technician & 5 & 4 \\
Seamstress & 0 & 1 \\
Singer & 0 & 0 \\
Stewardess & 1 & 4 \\
Teacher & 2 & 0 \\
Tour Guide & 3 & 0 \\
Typist/Office Clerk & 4 & 36 \\
\hline Total & 30 & \\
\hline
\end{tabular}

Source: See pp. 259 and 262.

occupational aspirations. Table 1 lists the occupations that they specified. None of the students mentioned any type of agricultural work. Obviously, the goals of sixty-six students do not permit any conclusions about the future aims of rural youth in general. Furthermore, even if we assume these students to be representative of rural youth, their aspirations do not ensure that they will not eventually work in agriculture. The present relationship between age and type of work on cooperative farms and these students' hopes do, however, suggest two points. First, young people who will work in agriculture will probably do so as highly trained technicians or specialists. Second, and more important, because of vastly improved educational opportunities, a diversified structure of employment options, and the impossibility of inheriting farm land, most young people in Dragalevtsy and Obnova do not assume or desire a future career in agriculture.

A third indication of change in the traditional peasant attachment to private land is provided by examining the age of the household members who work on the auxiliary plot available to families which have one member working on the cooperative farm. ${ }^{16}$ The data in table 2 show the percentage of one hundred seven

16. Thirty-eight of the sixty households interviewed in Dragalevtsy have auxiliary plots that average 877 square meters in size. All forty-seven households interviewed in Obnova have auxiliary plots that average 3,710 square meters in size. The smaller plots available in Dragalevtsy are an outcome of the land use policies of the capital city and its surrounding areas. 
Table 2. Household Division of Labor by Age, 1975-76 (in percent)

\begin{tabular}{|c|c|c|c|c|c|c|c|c|}
\hline \multirow[b]{2}{*}{ Activity } & \multicolumn{4}{|c|}{ Dragalevtsy } & \multicolumn{4}{|c|}{ Obnova } \\
\hline & $16-25$ & $26-40$ & $41-60$ & over 60 & $16-25$ & $26-40$ & $41-60$ & over 60 \\
\hline Planting & 29 & 33 & 88 & 57 & 67 & 71 & 87 & 67 \\
\hline Cultivating & 43 & 53 & 71 & 50 & 67 & 86 & 93 & 56 \\
\hline Harvesting & 43 & 60 & 100 & 71 & 67 & 46 & 87 & 67 \\
\hline
\end{tabular}

Source: See page 259 and notes 3 and 5 on the same page.

respondents from different age categories who said that they were responsible, at least in part, for the care of household auxiliary plots. ${ }^{17}$ (Several young people interviewed in Dragalevtsy did not even know what was grown on their family's auxiliary plot. When asked who would care for the plot after their parents or grandparents were unable to do so, many young people simply said "no one.") Table 2 indicates that Obnova has a higher proportion of people under the age of forty working on auxiliary plots than does Dragalevtsy. This too is explained by the small number of young people living in Obnova and by the limited employment opportunities in fields other than agriculture for those who do live there. The majority of Obnova's youth leave the village after the eighth grade to attend school or seek work outside the community. Obnova is not unusual in this respect; between 1947 and 1965, one and one-half million people moved from the Bulgarian countryside to the city and most of these people were young. ${ }^{18}$ As a consequence, the percentage of young people in rural areas is considerably smaller than the percentage of young people currently living in urban areas. ${ }^{19}$ The difference between the percentage of persons under forty years of age working on auxiliary plots in Dragalevtsy and Obnova is partly explained, therefore, by the fact that Dragalevtsy youth can live there and work or study in Sofia, whereas Obnova's youth cannot.

The dearth of young people in Obnova raises important questions about the future vitality of some Bulgarian villages. In the past, government authorities have encouraged the movement of rural labor to urban industry. ${ }^{20}$ Migration

17. A time-budget study conducted in $1970-71$ also shows that there is a clear relationship between age and the amount of time a person spends working on the auxiliary plot (see Ministry of Labor and Social Welfare, Budshet na aremeto na naselenicto $v$ N.R. Bulgaria prez 1970-71 (Time Budget of the Population of the People's Republic of Bulgaria during 1970-71) (Sofia, 1973), p. 16.

18. Velichko Dobrianov, "Changes in the Socio-Economic Structure of Bulgaria" in Thomas Butler, ed., Bulgaria Past and Present (Columbus, Ohio: AAASS Press, 1976), p. 152.

19. In 1970, 15 percent of the rural population and 31 percent of the urban population in Bulgaria was aged fifteen to twenty-nine (see figures cited by Huey Louis Kostanick, "Demographic Structure and Change," in Butler, Bulgaria Past and Present, p. 144).

20. According to Cyril Black, over one million persons were transferred from agricultural to nonagricultural employment between 1950 and 1968 (see Cyril Black, "The Process of Modernization: The Bulgarian Case," in Butler, Bulgaria Past and Present, p. 124). In 1934, 79.6 percent of Bulgaria's population lived in rural communities (see Statisticheski godishnik na Narodna Republika Bulgariia, 1974 [Sofia, 1974]). Today this figure is 42 percent (see Rabotnichesko delo, January 28, 1976, p. 2). 
peaked in the 1960s, but today there are several administrative restrictions on migration. Government authorities have also enthusiastically endorsed the equitable distribution of services and facilities to rural areas in order to eliminate some of the distinctions between village and town life and to inspire talented and ambitious youths to remain in the rural community. The result of these efforts has been a significant improvement in government services, commercial establishments, and cultural and entertainment opportunities in rural areas. Nevertheless, rural youths have sought jobs that match their levels of educational achievement, and these have usually been in the cities. Dispersing nonagricultural employment opportunities to the countryside may be the most effective way for Bulgaria to distribute the talents of her youth more evenly. Recent government decisions to locate new industry and relocate sections of old industries in nonmetropolitan areas reveal the government's awareness of this problem. Application of industrial technology to agricultural production in one hundred sixtythree new "agroindustrial complexes" may also contribute to the redress of certain growth imbalances by providing employment for skilled workers in rural areas. Whatever its merit as a form of organization for agricultural production, the agroindustrial complex may stimulate the growth of some villages by attracting trained youth. If so, it seems likely that the proportion of young people working on household auxiliary plots in Obnova would approximate that in Dragalevtsy today.

Finally, the socialization of agriculture in Bulgaria has rendered the connection between class, status, and land ownership obsolete. The legacy of traditional class inequalities where class positions have been defined as much by heritage, family name, and estate as by productive forces, dies hard. The families of important landowners before World War II are still well known in Dragalevtsy and Obnova, but the process of separating the historical convergence of landownership, status, and power is well under way. Socialized agriculture, rapid industrialization, and the resultant shift in employment opportunities for young people have dramatically altered the attachment to private land for which the grandparents of today's youth were so noted.

The second commonly cited attribute of a peasant population is the provincial nature of the peasant's social world. Social relations are generally confined within the peasant community. Ways of thinking, acting, and believing are passed from a dying to a growing generation with little input from outside the community. Peasants are considered impervious to urban culture and suspicious of outsiders, with the village as their sole reference point; all socially meaningful activity is contained within the network of local community relations. This profile of peasant society is probably overstated for Dragalevtsy in the 1930s, because the prewar economic links between Dragalevtsy farmers and urban markets was significant. Fourteen percent of the heads of farming households traveled by cart to Sofia each day to sell milk; one-half did so every week. Urban intelligentsia had penetrated the local community as heads of service institutions and were responsible to national ministries, such as health and education. Many tourists and residents of Sofia passed through the village each day on their way up Mount Vitosha to hike, picnic, and visit the fourteenth-century monastery near the village. 
Having said this, it is nevertheless true that Dragalevtsy was socially, psychologically, and spatially removed from the capital city which today seems so near. Most of the residents of Dragalevtsy in 1934 found their spouses within the local community or in one of the nearby villages, not in Sofia. The majority of the men who grew up in Dragalevtsy were content to stay and farm their fathers' lands. Even the farmers who traveled to Sofia moved in distinctly "peasant circles" once they arrived in the capital - the peasant market and a few bars that were frequented by fellow villagers. Few used Sofia's cultural advantages. Few were employed in the city. Friendships and recreation were most often found within the village; if one found either outside of Dragalevtsy it was invariably with persons from the two closest villages. Parents were loath to allow their children to go to the city. Contact with events outside the community was limited. Dragalevtsy residents were rarely entangled in business or friendship networks beyond the borders of their village. The provincial social orientation found in prewar Dragalevtsy was undoubtedly even more pronounced in Obnova, because it was located further from any urban center. The situation is, of course, greatly different in both communities today.

The progressive breakdown in the isolation of the prewar rural community has many causes, but the primary ones are the changes in the economic structure that have necessitated shifts in the labor force and political changes that have required increased contact between local institutions and those at the regional or national level. In the last thirty years, the surplus agricultural population in Dragalevtsy has found employment in the expanding industrial establishments of Sofia, where one-fourth of Bulgaria's industrial enterprises are located. Employment was not hard to find for those who were willing to continue to live in Dragalevtsy and thus not put additional pressure on the limited housing situation in Sofia. As Dragalevtsy's residents have increasingly gone to the city for work, education, and entertainment, the local community has been increasingly penetrated by Sofia residents. Most of the people who now work in Dragalevtsy's commercial establishments, health clinic, and schools are not from Dragalevtsy and usually live in Sofia. Only two of twenty-five of Dragalevtsy's school teachers are originally from the community and only five now reside there. All eight of the teachers in the new nursery school live in Sofia. Even Dragalevtsy's priest lives in Sofia. In addition to this "professional penetration," 1,069 villas have been built in a special section of Dragalevtsy for Sofia residents.

One simple illustration of Dragalevtsy's increased entanglement with business or friends outside the community can be seen in the enormous increase in the flow of mail into and out of the community. The population, however, has less than doubled over the last forty years. ${ }^{21}$ In 1934, an average of 10 letters was received each day in Dragalevtsy. ${ }^{22}$ During the week that I monitored the flow of mail in the Dragalevtsy post office (January 2-9, 1976), 432 letters were mailed to Dragalevtsy and 255 letters were mailed from the local post office. ${ }^{23}$ In 1934, only 21 newspaper subscriptions and 7 magazine subscriptions were

21. The population in Dragalevtsy in 1934 was 2,204 . In 1975 , it was 3,986 .

22. Irwin T. Sanders, "The Sociology of a Bulgarian Shopski Village" (Ph.D. diss., Cornell University, 1938), p. 105.

23. Of the 432 letters delivered to Dragalevtsy, 178 originated in Sofia. Of the 225 letters mailed from the Dragalevtsy post office, 121 were mailed to addresses in Sofia. 
delivered to Dragalevtsy. Today there are 995 subscriptions to 35 different newspapers and 649 subscriptions to 104 different magazines and journals delivered to Dragalevtsy residents by the post office. ${ }^{24}$

Dragalevtsy residents also make more frequent use of Sofia's cultural facilities. In 1934, 55 percent of Dragalevtsy's adult population had never seen a movie. Eighteen percent of the women and 5.6 percent of the men had never even been to Sofia. Today, 63 percent of the people interviewed in Dragalevtsy travel to Sofia every day, and fully two-thirds of the respondents attend a movie in Sofia at least once a month. Fifty-five percent have attended the Sofia opera at least once in their lives, 20 percent have gone to the ballet, 87 percent to the theater, and 12 percent to a concert. Television constitutes another way in which the people of Dragalevtsy have become exposed to events outside their community: fifty-five of the sixty households interviewed have a television, and 83 percent of the respondents watch at least one hour of programing from Sofia daily.

Because it is located so near the capital, Dragalevtsy is understandably more involved with urban life than Obnova or most of Bulgaria's other 5,512 villages. Its location has certainly affected Dragalevtsy's use of extracommunity facilities and services and has accelerated the penetration of urban ways and people into the community. Nevertheless, Obnova's residents have also become increasingly involved in social, economic, and educational networks outside the local community. A few isolated facts illustrate the ways in which people living in Obnova now make use of urban areas. Of the forty-seven people interviewed, 61 percent travel to the district capital of Pleven at least once a month (23 percent weekly) for various purposes, especially shopping. Most of Obnova's three hundred students will pursue their education in the larger cities of the area after completing the eighth grade in the local school (all eighth-grade graduates did so in 1975). There are also about one hundred residents of Obnova who commute to jobs in Pleven, Levski, or other industrial centers. On the other hand, a number of the people who are employed in Obnova (especially the ninety-five individuals in service occupations) come from outside the local community. ${ }^{25}$ For example, the dentist and the ambulance driver are the only two of the seven members of the medical staff at the local clinic who originally came from Obnova. Half of the twenty-two teachers in the school are originally from outside the local community.

In addition to the interchange of rural and urban personnel, Obnova is increasingly exposed to the national system of information delivery and enter-

24. Of these 649 subscriptions, there were 31 subscriptions to 10 different German magazines, 24 subscriptions to 8 different Russian newspapers, and 156 subscriptions to 81 different magazines and journals from the Soviet Union.

25. The dispersal of services and professionally trained personnel to rural communities is assisted by a program of labor distribution that is administered by the Ministry of Labor and Social Care and the Committee for Scientific and Technical Progress. The first plan to allocate specialists was made in 1950 . Today about fifteen thousand specialists who graduate from universities or secondary technical schools are annually assigned to work for three years in places that demonstrate a need for particular specialists. Over one-fourth of these specialists are assigned positions in Sofia, and other large towns also receive a large share of new professionals. But rural communities such as Obnova are supplied with the teachers, doctors, nurses, or other service and technical personnel considered necessary by local institutions and agencies. 
tainment, much like Dragalevtsy. There are, for example, 873 daily newspapers delivered to Obnova residents each day, and 88 percent of Obnova households subscribe to at least one magazine. ${ }^{26}$ All of the households interviewed in Obnova had a television set in 1976, and most respondents watched some programing every day. Obnova's involvement with husiness or friends outside the community is illustrated by the fact that the post office received 1,100 pieces of mail and sent 854 pieces during the week the flow was monitored (April 1-7, 1976). Obnova's population also takes advantage of the cultural and entertainment opportunities available in the local cultural center or in a nearby city, although not to the same extent as residents of Dragalevtsy. Sixty-two percent of the respondents attend the cinema at least once a month, 28 percent have gone to an opera at least once in their lives, 13 percent to the ballet, 62 percent to the theater, and 9 percent to a concert.

Dragalevtsy's proximity to Sofia may exaggerate certain types of changes in community and family life, but these changes are not unique to Dragalevtsy. Obnova, as well as Dragalevtsy, has been a part of the national system of information delivery, entertainment, and culture. Working people in both communities are affected by the national structure of educational and employment opportunities. Similar health, education, and government services are available to residents in both communities. The processes of moving the village to the city and the city to the village have created a situation in the $1970 \mathrm{~s}$ in which it is no longer meaningful to refer to the "narrow village social orientation" of the people who live in Dragalevtsy or Obnova.

Finally, in regard to the characteristic of patriarchal familism, it is interesting to examine briefly several aspects of the contintity and change in the role of women and in the function of extended kinship relations in Dragalevtsy and Obnova family life in the late 1970 s. The joint family (or family commune) as a sociohistorical form was quite common in Bulgaria's past. In the nineteenth century, the joint family (known as the zadruga among the South Slavs) in western Bulgaria involved either several households located in one courtyard with one serving as the paternal house, or one large house for all members. The senior male member stood at the head of the joint family. In 1886, I. E. Geshov noted that Dragalevtsy had two flourishing zadrugas--the Alulovs (with thirtysix members) and the Danevs (with thirty-four). ${ }^{27}$ The decline of the zadruga as a family structure began in the nineteenth century and, by the beginning of this century, it had virtually disappeared in Bulgaria.

Professor Sanders found no zadrugas in Dragalevtsy in 1934, but he did find the persistence of patriarchal authority and a high incidence of three- and four-generation households. In 1934, 60 percent of Dragalevtsy households were made up of at least three generations. In 1976, half of the households interviewed in Dragalevtsy and 62 percent in Obnova were composed of at least three generations. Similar statistical results for 1934 and 1976 for Dragalevtsy may, however, mask changes in the underlying sociological reasons for the existence of threegeneration households. In the 1930s, three-generation households were common

26. This figure has been determined from Obnova post office records.

27. Cited by Sanders, "The Sociology of a Bulgarian Shopski Village," p. 161. 
because of the need to pool labor for work on the family farm, which is obviously not the case today.

The three-generation household continues to be common in Dragalevtsy and Obnova today for two major reasons. First, newly married couples find it difficult to settle in separate dwellings. For a young married couple in Dragalevtsy, purchasing a new apartment in Sofia costs at least ten or twelve thousand leva and requires years of waiting on a list of prospective buyers. ${ }^{28}$ Building a new house in either community demands years of saving. Only five of the forty-eight married persons interviewed in Dragalevtsy and only two of the thirty-nine married respondents in Obnova resided in a dwelling separate from their parents immediately after their marriage (most living in the husband's family house). With most couples having a child within the first few years of marriage, it is not surprising that three-generation households result from the financial burdens of neolocal residence. The second factor serving to perpetuate the three-generation household is the fact that today most women in Bulgaria work outside the home. In 1976, 82 percent of working-age women (from nineteen to fifty-four years old) were working or studying outside the home. ${ }^{29}$ In the course of my research, I found only two working-age women in Dragalevtsy and two in Obnova who were not employed outside the home. ${ }^{30}$ Moreover, all but three of the men and women interviewed in both communities felt that it was desirable for women to work outside the home, most specifying the necessity of the contribution of the working woman's wages to the household budget. The dramatic increase in the number of women working outside the home has had four notable consequences for the Bulgarian family as a social institution: (1) the status and self-image of Bulgarian working women has improved significantly; (2) the woman's socializing role as mother is increasingly being shared with others; (3) the birth rate has decreased drastically; and (4) the woman's new role as wage-earner has not diminished her duties as homemaker. For the purposes of this paper, I will comment briefly on only the last of these consequences.

Even though many women are now working an eight-hour day outside the home, they are still expected to handle the bulk of household responsibilities. A recent time-budget study showed that Bulgarian working women spend an average of 257 minutes per day on household chores, whereas working men spend an average of 125 minutes per day. ${ }^{31}$ Table 3 shows the different responsibilities of the men and women interviewed. The data suggest that the underlying cultural definition of the woman's role in the home has not been seriously eroded by administrative measures or by the sincere ideological efforts of authorities to exorcise a spirit of male domination in the home that has been in the making for centuries.

Three options are available for relieving the overburdened Bulgarian working woman from what Lenin once called "the unproductive, petty, nerve-racking, stultifying, and crushing drudgery of work in the house."32 First, the division of

28. In 1976 , one lev was said to be worth ninety-seven cents.

29. Sofia Nezes, February 19-25, 1976, p. 1.

30. This number excludes students and women on temporary leave from work for childcare purposes.

31. Ministry of Labor and Social Welfare, Budzhet na vremeto, p. 10.

32. As quoted by Hilda Scott, Does Socialism Liberate Women? (Boston: Beacon Press, 1974), p. 169. 
Table 3. Household Division of Labor by Sex, 1975-76 (in percent ${ }^{\text {a }}$ )

\begin{tabular}{lcccc}
\hline & \multicolumn{2}{c}{ Dragalevtsy } & \multicolumn{2}{c}{ Obnova } \\
\cline { 5 - 6 } Activity & Men & Women & Men & Women \\
\hline Housecleaning & 25 & 90 & 30 & 100 \\
Meal Planning & 28 & 68 & 30 & 85 \\
Meal Preparation & 21 & 68 & 4 & 90 \\
Serving Meals & 17 & 84 & 7 & 85 \\
Dish Washing & 10 & 87 & 0 & 85 \\
Sewing Clothes & 3 & 19 & 0 & 70 \\
Mending Clothes & 7 & 55 & 78 & 65 \\
Plantingb & 59 & 48 & 70 & 65 \\
Cultivating & 76 & 36 & 85 & 70 \\
Harvestingb & 83 & 58 & 69 & 58 \\
Managing Finances & 69 & 50 & &
\end{tabular}

a Indicates percentage of one hundred and seven respondents claiming at least partial responsibility for various chores.

$b$ Refers to the plot around the house or the auxiliary plot provided to members of the cooperative farm.

Source: See page 259 and notes 3 and 5 on the same page.

household labor may be democratized so that husbands assume equal responsibility with their wives for household care. This has happened in some families to a certain extent, and it may become more common in the future, but it is clear that this is not the general situation today, especially in rural families. Second, the burdens of household work may be shortened and lightened with improvements in the national service econony (laundries for example) and the increased availability of labor-saving household appliances. ${ }^{33}$ Because private housekeeping has not yet been transformed into a public industry and because helping husbands still expect their occasional household efforts to be congratulated, a third alternative is for the working mother to rely on parents, parents-in-law, or other relatives to help care for the children and share the responsibilities of maintaining the house. In a curious way, policies designed to individualize labor and to break down the functions of traditional patriarchal familism have simultaneously created a situational dilemma for working couples and parents which perpetuates the function of strong familial dependencies, especially the three-generation household.

Although the differences between Dragalevtsy and Obnova are noteworthy, I have sought to underscore the ways in which both communities are participating in and experiencing similar contemporary processes of change. Their shared experiences of continuity and change suggest certain observations about the process of socialist planned change for Bulgarian communities and families in the late 1970 s and the 1980s. Many of the changes in Bulgarian community and family life since 1944 can be interpreted as the outcome of "depeasantization."

33. At the time the research was conducted, 85 percent of the sampled households in Dragalevtsy and 87 percent in Obnova had washing machines, 55 percent in Dragalevtsy and 26 percent in Obnova had vacuum cleaners. These conveniences undoubtedly lighten certain traditional household chores but probably do not significantly lessen the time spent on such chores. 
The Bulgarian Communist Party has designed and implemented a series of policies intended to transform much of the sociological legacy of presocialist rural life. The process of "depeasantization" has, however, proceeded unevenly, transforming certain prewar peasant attributes more extensively than others. Production relations, for example, have yielded to change more quickly and easily than familial relations. Furthermore, the planned socialist reconstruction of Bulgarian rural life has not affected all people in the same way. People who participate in the same historical moment often do so from different biographical vantage points. For each of the social attributes considered in this paper, age is consistently the most significant variable and it differentiates the attitudes and behavior of residents of Dragalevtsy and Obnova.

In casual conversations with inhabitants of Dragalevtsy, I often asked them what the biggest change in Bulgaria in their lifetime was. Many people mentioned the assumption of "people's power," the availability of free medical services or free education, the great improvement in the standard of living in the last thirty years, the introduction of the five-day work week, and the availability of household conveniences. Others, however, seem to tolerate certain changes by ignoring them. There are older women, for example, who sweep their homes clean with brooms and leave their daughters' new vacuum cleaners in the closet. Others use the cellar or window ledges to cool food during the winter and their unplugged refrigerators as shelves. Finally, several people actually bemoan the loss of a way of life they once knew. An eighty-year-old man sadly summarized his attitudes about the changes in his community by saying, "I cannot let my chickens run loose any more with all the traffic." Allowing for some very notable exceptions, it may be as one Bulgarian said, "There are young Bulgarian villagers today but there are only old peasants."

Peasant traditionalism and socialist modernity are not mutually exclusive. The transformation of the Bulgarian rural community and family has been profound. Yet, as some traditional peasant attributes of rural life have lost their contemporary meaning in the face of change, others have been modified or adapted. The dynamic interaction between presocialist societal attributes and the goals of Bulgarian rural reconstruction makes it clear that, if we are to understand the contemporary situation in Bulgarian communities or families, we must consider the inherited past as well as the anticipated future. 